\title{
CHILDREN AND YOUTH FACE OF THE MIGRATION
}

\author{
*Zsuzsanna Dr. Dabasi-Halász, \\ *Ágnes Hegyi-Kéri \\ University of Miskolc, Hungary
}

\begin{abstract}
Population trends influence the size and composition of the whole that and, consequently, those of the labour source. In the second half of the 20th century demographic processes were characterized by low and stable levels of mortality and fertility, the natural growth of the population stopped. Hungary's accession to the European Union, has changed Hungary's labour market in the past few decades. It placed our region into the migration processes, the reasons for and consequences of which is slowly deciphered by the domestic science. The migration has-a children face, which is quite new research area both in Hungary and in the Easter countries. My aim is with this article to answer the following research question regarding to the immigration and emigration process. How can the mobility of young people and children be 'good' both for socio-economic development and for individual development of young people and children, and what are the factors that foster/hinder such beneficial mobility? My research answers could help to know more about the advantages of the young people and children mobility as for the aspect of the socio-economic.
\end{abstract}

Keywords: Immigration, Emigration Process, Migration Strategy

\section{INTRODUCTION}

The Europe 2020 strategy can see the young generation as a driving force for smart, sustainable and economic growth because young people are most likely to take the risk to move abroad for educational or work-related reasons and to contribute to social and economical development with innovative business strategies (Eurofound 2011). However, in view of the large number of young unemployed people in Europe some call the 16-29 years old the ,lost generation', shut out from productive activity. Especially, young people are therefore addressed by intra-EU mobility programs. The economic downfall has led to a situation with high unemployment rates of young people in some countries. In other countries there is a manpower shortage in some areas requiring specific qualifications. At the same time lack of internal mobility on the European labour market still persists: "While 4.1 percent of EU residents are from outside the European Union, only 2.5 percent are EU nationals living in another Member State" (Benton and Petrovic 2013).Merits and impacts of the freedom of mobility in the EU are intensively discussed on the political agenda: On the one hand the right to work, live and retire in another EU Member State can have numerous social, cultural and economic benefits such as "efficient labour markets, increased cultural exchanges, better-trained workers, and the opportunity for citizens to broaden their horizons" (Benton and Petrovic 2013)On the other hand the economic crisis in Europe and the enlargement of the EU have raised doubts on the positive impacts of the freedom of movement. As a consequence, the 'old member states' of the EU have set 'transitional arrangements' to protect their labour markets from the workers of the newest member states (NMS) because they fear a huge wave of immigration. This fear has been proven to be mostly unfounded. Conclusion of the report 'Mobility in Europe: The way forward' based on data of the 2005 Barometer was that "geographical mobility in general tends to be higher in the Nordic countries; by contrast in most of the NMS and in most of the southern European countries, mobility within or outside the region is relatively low" (Eurofound 2011). Nowadays, the question is how the economic crisis in several countries has an impact on the mobility of young people. At the same time, the negative effects for the sending countries in regard to the movement of workers is now also a major concern (Queirós 2010) especially when high-qualified people who receive lowincomes in their home countries choose to emigrate (OECD 2006). Once citizens have freedom to move to other EU-countries this mobility can intensify regional crisis and economic downturn in the sending countries. In terms of a deep economic crisis specifically the younger generations are forced to emigrate which can have negative effects like the disruption of families. 


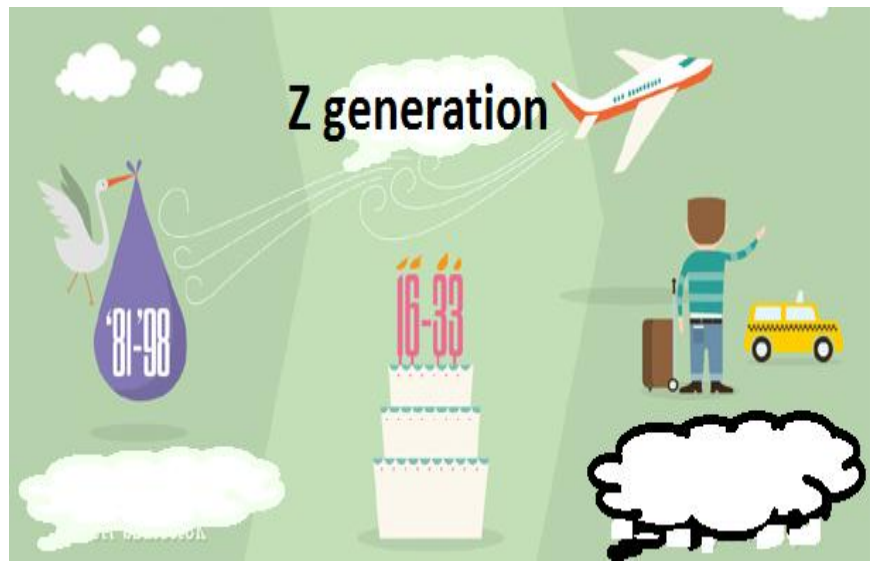

\section{Figure $\mathrm{Y}$ and $\mathrm{Z}$ generation' migration attitude (own addition )}

The central statement of my article has been that the competitiveness of Northern Hungary and the international migration affecting the County are closely linked, the international migration can be influenced and it is important that the region's economic policy pays more attention to the labour migration processes. In this article I mention the reasons of the youth migration from the Northern Hungarian region. I also mention the economic and social effects of this youth migration as problem issue in this region. My hypothesis is the following: After the Northern Hungarian region was not able to find a successful economic development pathway, the children of the economic structure change generation, the so called $\mathrm{Z}$ generation was on to migration. The reason of that mainly the depressed labour market.

\section{THEORETICAL BACKGROUND}

The approaches of the English classical economists, such as Smith (1776), are important for researchers of migration because they suggested that labour is the prime mover of the economy, it is the source of value. Later, those migration approaches built upon this theorem, which I also treat as an axiom, that wished to aggregate the gains and losses of the labour allocation processes at a macro-economic level. Piore (1979), in his writings, pointed it out that there is a constant hunger for immigrants in industrial societies because this need follows from their internal operation. The work of Malthus (1798) indicates that the change in the number of the population is an important economic factor; and it may be easy to econometrically prove a theorem which will be refuted by the history, and which induces adverse social processes influential to the economy. Racism falls into this category: the ideology which keeps it alive are the over-population and "living-space" theories. The European migration studies of the 20th century have been influenced by the vision that hungry crowds are coming to the developed West European countries and, in search of work and bread, are over-populating them. Migration researches, therefore, got a new direction that aimed at proving this theory mathematically. Estimations trying to estimate the East European migration trends on the basis of the migration experiences of the South American expansion rest on the econometric models stemming from the differences in pay. (Bauer and Zimmermann 1999) Ricardo's (1817) labour value theory is also the basis of economics of migration. He suggests that the manufacturing cost is one of the movers of foreign trade. Pay ratios, pays being one element of manufacturing costs, are also the movers of migration. This means that a researcher of migration regards the relationship between trade and labour migration as important. According to Say's dogma every production create its market, that is, neither a general oversupply or a general unemployment are possible. His followers might have misunderstood his statement and overemphasized its importance. Perhaps the best known theory, based upon the previous ideas of the classical economics, is the behaviourist "push and pull theory". Ravenstein (1889) claims that basically individual decisions have to be investigated. In his view migration is governed by a "push-pull" process: unfavourable conditions in one place (oppressive laws, heavy taxation, etc.) "push" people out, and favourable conditions in an external location "pull" them in. Ravenstein, however, disregards labour market situations. (Tobler, 1995) The neoclassical schools of thought, based on the marginal productivity concept, came to the logical explanation that the relative factor-supply of particular countries differs from one another. In the lack of state intervention in a national economy, factor owners' transfer factors to locations where their prices and 
revenues from them are higher. This explanation seems to be simple and acceptable, and consequently, it exists in public thinking, it influences politicians and economic leaders in making decisions. Harris and Todaro (1970) developed a model, following the neoclassical economists, by way of which they attempted to follow the strengthening econometric approach. I contend that the most remarkable importance of the model is that migration, previously investigated from geographical and sociological aspects, had directly become researchable using economic logic. Marx's (1868) views are also important from the point of view of labour migration. He argues that every method of production has its own social embeddedness. Therefore, I can accept that migration processes can be interpreted only in a socially adequate environment. Logical connections and historical observations play important roles in understanding migration processes. At the beginning of the 1970ies new approaches emerged that explicitly refused the neoclassical "pull and push" interpretations. The emphasis shifted to macro-processes and wider historical/structural forces since thy, rather than the micro-context of individual decisions, determine the preconditions and direction of labour flow. They do not consider labour migration to be an independent phenomenon: they investigate it as a significant component of the uneven development among sectors, regions and nations (Wallerstein 1983). Schumpeter's (1912) work cannot be overlooked in a literature review concerning migration. In his theory economic growth is in close relationship with intellectual capital, knowledge, R\&D capacity, information and entrepreneurial skills. Schumpeter's entrepreneur is a factor of production that emigrates or immigrates and, in this way, significantly influences an economy's production ability. In my view it may be seen as a basis of the adverse consequences of brain-drain in the economic theory. The neoclassical revolution could only provide "add-on"-s to the classical theories: it offered "post-factum" explanations to questions relating factors of production, including migration. Keynesian economics suggests that the state has a central role in controlling migration processes. It is not necessary or rather not possible to mathematically prove certain observations and theories. The Austrian School of Thought paid relatively a little attention to labour market issues. Its general approach is that it refuses planning and state intervention and governance. Its liberalism suggests that market needs channel labour migration in the appropriate direction without state intervention. This school had an obvious role in the free movement of people and labour mobility in the 20th century. The "New Economics" questions a number of conclusions of the above mentioned theories. Many of the representatives of neo-Keynesians, post- Keynesians, the new institutional school and new-Marxists were concerned with the significance of human capital and related issues. Their theorems influence the economics of migration. The neoclassical paradigm was then replaced by the, so called, endogeneous growth-theory which analyses economic growth by explicitly modelling technical development and human capital accumulation. The highly trained workforce is attracted by the "knowledge factories", the intellectual capital tends to be concentrated. Therefore, poor countries' growth will be slower than that of richer ones. Researchers of the endogeneous growth-theory dealt a lot with the impact of governmental policy on economic growth. Their views influenced the investigation of the migration of scientific degree holders. Representative of the new institutional school assert that market behaviour cannot be analyzed through the behaviour of individual actors. By saying this they question the classical approach of migration based on individual pay differences. The institutions (which are not the organizations themselves, they are rather behavioural systems) appear as independent factors in the market, they have their own goals, thus their role modifies the conditions and characteristics of market equilibrium. Studying the institutional environment leads us to the network theory (Portes and Walton 1981, Castells 1989, Sassen 1988). If the relatives, friends, neighbours and workmates have relationship in the potential target area, it can minimize the migrant's risk if he or she can rely on the already existing interpersonal networks for information (Taylor 1976). One aspect of the further development of the model is the problem of building relationships. Swaan (1994) points out the lack of institutions of relationship-building in the transitional economies. Building relationships is necessary and costly; however if those relationships exist already it will significantly decrease transactional cost and increase yields. The research of the new institutional school can be seen as the beginning of investigating problems that had been ignored by the traditional economics (Mátyás 1996). Balogh (1993) argues that world is getting smaller, it tends to be unified, we live in an age of interdependence and there is only one worldeconomy and world-trade system. A new world order is shaping up, the basis of which is globalization. It pervades a great deal of migration theories following Wallerstein's (1983) work. New economics, which introduces production from a new perspective, is gaining more and more emphasis in famous economists' publications. They tend to suggest that the conditions and circumstances of production have radically changed following the structural changes of the past twenty years. The factors of production do not mean the 
traditional land-capital-labour triumvirate any longer (Landfeld-Fraumeni 2001). One pillar of this new system is human resource that uses the, so called, "info communication". All these changes tend to put migration on a new footing.

\section{CHILDREN AND YOUTH FACE OF THE MIGRATION}

With the terminology of 'mobility patterns' I intend to emphasise that considering an analytical perspective young people's mobility emerges at the intersection of several aspects that are not reducible to a specific form of mobility as student or work mobility. Instead, mobility patterns combine different forms taking into account the situational conditions and the variations over time. Additionally, these patterns include practices of virtual mobility before, during and after staying abroad; and also temporary cross-border movements during the stay abroad back to the countries of origin and after having returned to the countries of origin to the places at which people stayed during their temporary mobility (Frändberg 2014). Based on life course theory (Elder 1995) young people act according to their life stage, the opportunities related to that stage and their preferences while manoeuvring through that life stage (Mills and Blossfeld 2005; Walther 2001). This is in line with studies that show that return migration (back to the country of origin) is much likely around the age of 30 and around the age of retirement (Kuhlenkasper 2012): In the light of the theory of social reproduction (Bourdieu 1984) I assume, that a preference for mobility is strongly related to the position of the young person (and its family) in the social space and therefore depends on the young person's economic, cultural and social resources (Skrobanek and Jobst 2006). Thus, dependent on their economic, social and cultural background young people actively define the situation they live in and actively choose - framed by this definition - those mobility opportunities that fits with their given beliefs and desires, their social background and the given life stage specific constraints (Elder 1995). So, young people are not objects but subjects of the situation they are confronted with (Bynner 2005; Elder 1995). However, their options are limited by circumstances in which they live (Mills and Blossfeld 2005; Walther 2001). Within the frame of an on-going individualization, new opportunities of mobility can - on the level of the individual - be seen as possibilities of free choice, but are also connected with greater risks and insecurity (Frändberg 2014; Bukodi and Róbert 2007). This of course has effects on the young people themselves as well as for social relations, institutions, and forms of learning, working and living - in our case for their international mobility or immobility and the regions where the young people come from or where they go. This framework allows for a refined analysis of the mobility patterns, and the achievement of agency or lack thereof in regard of crossborder mobility. It is also helpful to identify the individual, structural and institutional factors, conditions and arrangements that can enhance and support young people's agency in relation to mobility. The mobility patterns of young people have to be grounded in a perspective on young people's transitions to adulthood (Frändberg2014). At the same time, the perspective on agency can be linked to questions of social participation and active citizenship as these can foster each other. They can also be economically e.g. when mobile young people transfer money to their countries of origin. Within this transnational perspective also gendered dynamics of mobility and migration likewise become more visible since they "demand a more intimate look at the nature and 'quality' of the migration process in terms of social integration, professional ascendance, financial security, and general well-being” (Stalford 2009)

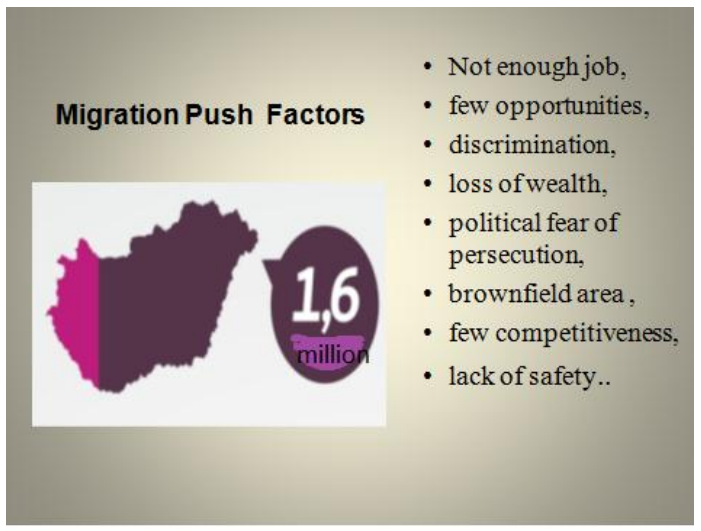

2. Figure: Migration pusch factors in Hungary in the 21th century 


\section{CASE STUDY REGION WITH REGARD TO THE EUROPEAN CONTEXT}

The 2006 conference of the UNO in international migration and development confirmed the relationship between emigration of individuals and the development of the country of origin. Although it did not draw firm conclusions about the nature of this relationship, it pointed out that migration and development are interrelated, this relationship is complex and further inquiries should be made into this issue. Recommendations so far have placed emphasis on the demands of the host country rather than the immigrant or the needs of the country of origin. At the same time, the American Congress also addressed the immigration reform. However, the negotiations did not deal with the impacts of the suggested reforms on the development of the country of origin.

Hungary has gradually been present in the migration processes. Population of the European continent is decreasing which issue is the most significant in the East European countries. The most remarkable decline may happen in Bulgaria and Russia. The former may lose $38 \%$ of its population of 7.8 billion, whereas, in the latter one, the population will decrease by $17 \%$, that is, by 25 million people. According to the forecasts, Hungary's population of 10.1 million will be 8.9 million in 2025 and 8 million in 2050. Our neighbouring countries' population is also diminishing considerably. Although the migration loss is difficult to be proven in east European countries and in central-east European countries, it can be prognosticated, and it will have demonstrable macro-economic consequences.

According to my hypotheses there is a considerable internal and international migration in Hungary, with special regard to the economically backward counties. The growth of the population has slowed down in these regions, with the exception of some special sub-regions, the decrease of the population can be observed. It comes, apart from the low number of birth, from the negative balance of migration. The emigration of the population causes a vicious circle because it brings about labour shortage which, aggravated by the bad economic situation, exerts a push effect to the mobile part of the population. Hungary is also involved in the quickening of the international migration, the EU accession just strengthened people's willingness to migrate. I assert that the migration potential is large and increasing in North-Hungary. The motivation and willingness are different in the case of the various social strata.

Some large nations have prepared to the treatment of the growing migration in their migration policies, in which coordination and precise data collection get an outstanding role. The techniques of managing migration do not exist in Hungary. A well segmented migration policy is very important for the future. I put forth the findings of the primary survey I have conducted in the recent several years in the third chapter of my researches. According to the Hungarian Central Statistical Office database the GDP per capita was 22 thousand USD in Hungary in 2012. In Hungary the difference between the most and least developed region is 2,4-fold. Only the income level in the region of the capital city exceeds the European Union's average it increased 6 percent between 2004 and 2007.Based on Hungarian Central Statistical Office data, NorthHungary's GDP accounted for 7,9\% of the national GDP in 2012, whereas the population of the region represents $11,96 \%$ of the Hungarian population. GDP per capita was USD 12 thousand, which is $60,3 \%$ of national average and 36,5\% of EU28 average measured at purchasing power parities (PPP). In line with the national tendency, the service sector accounts for more than half of the regional GDP. North Hungary is the fourth largest region with one of the highest population density in the country. Out of 605 settlements 39 are towns comprising approximately half of the regional residents. The population potential of the region is satisfied, but the economic potential has proved to be inadequate. Among the Hungarian regions the most disadvantaged region is North Hungary with $16 \%$ unemployment rate. Compared to EU data the unemployment rate is 10 percent. In the other six regions a slow growth of GDP can be recognized. The income gap increased in the examined period between Central Hungary and the other regions, the standard deviation increased from 34 percent to 38 percent. In Northern Hungary the growth rate is very low, so the region's position has changed neither in the European Union nor in the local hierarchy in the examined period. In the counties of Northern Hungary the growth of GDP per capita is mor e than 4 percent. 


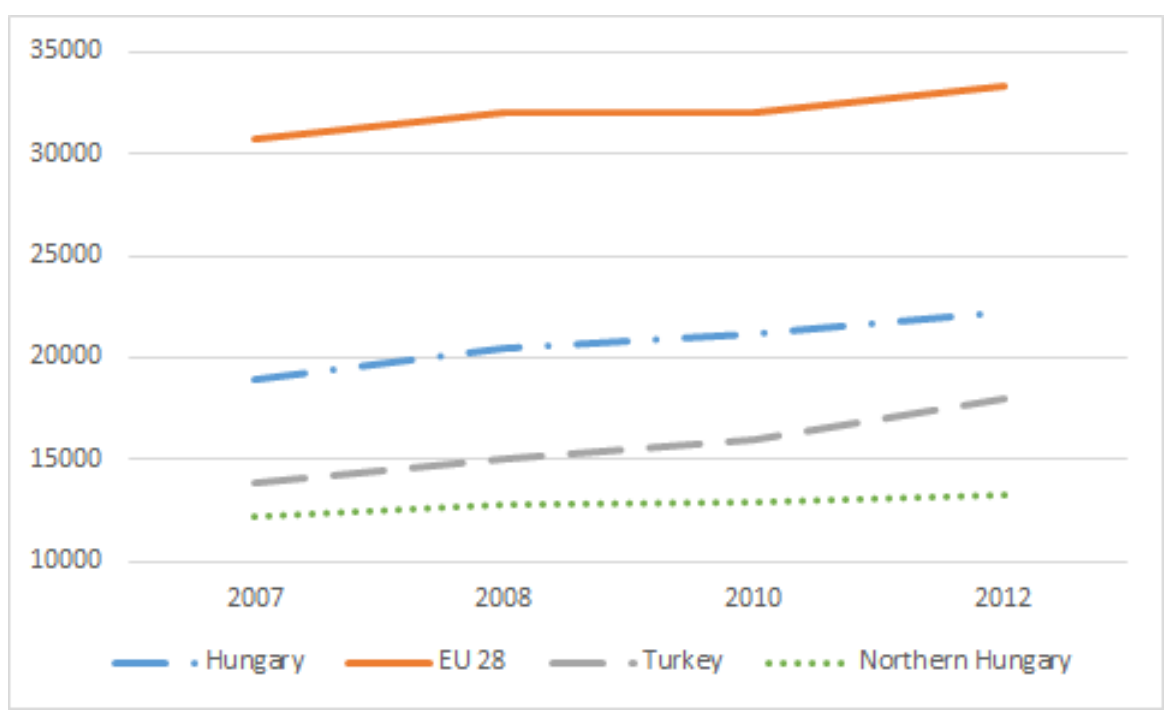

\section{Figure 3. GDP per capita in Northern Hungary}

Source: own compilation

Demographic development can be characterised by the number of population. The decline in the number of population was only interrupted twice in the past twenty years. Firstly it happened in 1995, when the number of population slightly increased by 0.8 percent.

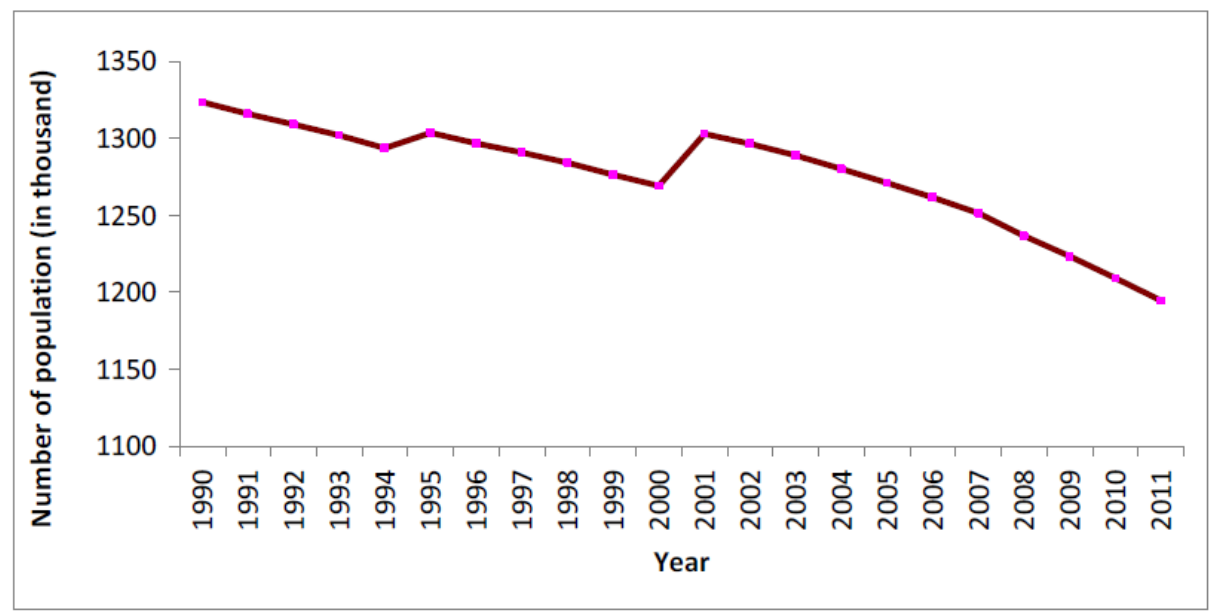

\section{Figure 4. Population of Northern Hungary (1990 - 2011)}

Source: own compilation based on data from www.ksh.hu and www.registar.hu

Besides looking at the total number and the changes of population, its composition is also worth to examin. Population changes can have two sources: vital events and migration. Vital events include birth and death and natural increase or decrease expresses the sum of these two factors.

In the examined period the balance was always negative regarding the analized territories, but in Northern Hungary, the natural decrease was always higher. Even if the live birth for thousand inhabitants is higher in the region than the national average, deaths per thousand inhabitants is also higher. It is notable that one of the highest fertility rate indicators can be found in Northern Hungary. This is due to the fact that fertility rate is extremely high among women younger than 14 (which is three times higher than the national average) and women between 15 and 19 years (twice as high as the national average), while the fertility rate of those above 25 is lower than in Hungary. This leads to the unfavourable fact that young mother get out of the education system, do not get any qualification and thus cannot reach the living standard is necessary to 
satisfy the minimum needs. Early founding of family can be a reason for poverty and deprivation. Changes in the number of the population can be caused also by migration. In the case of Northern Hungary, this measure is the sum of internal and international net migration, while in national level this is equal to the international net migration. While net migration in Hungary has been positive, in the case of Northern Hungary it has always been negative.

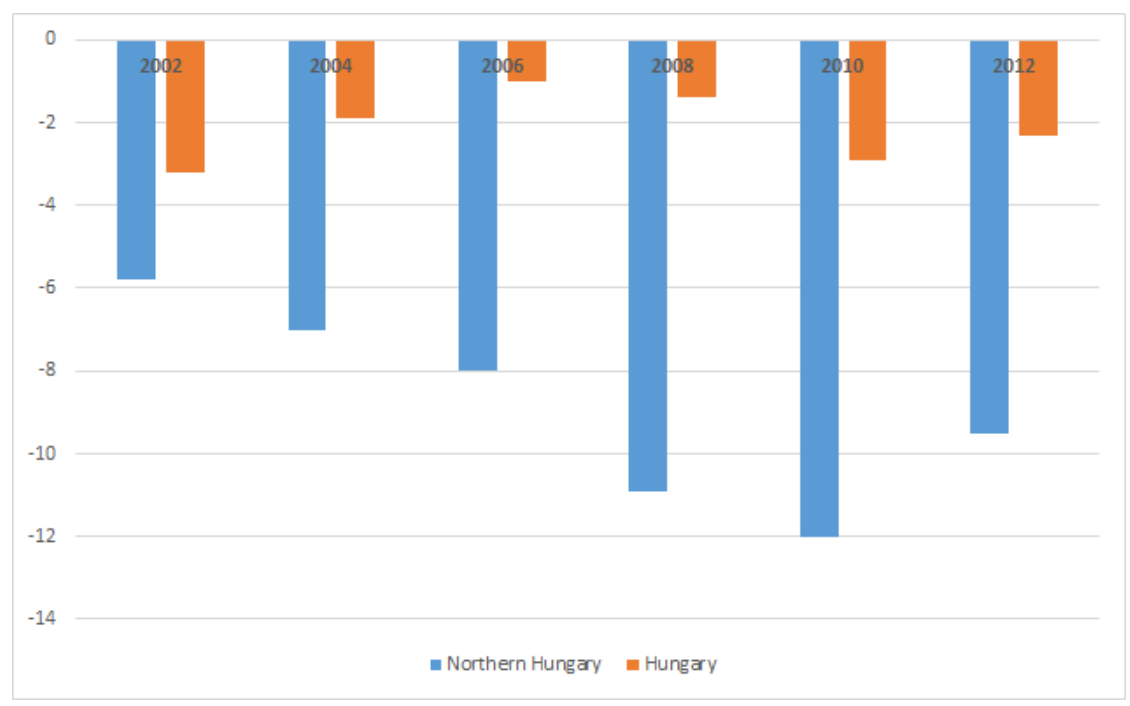

\section{Figure 3. increase (+) and decrease (-) per thousand inhabitants (2001-2010)}

Source: own compilation based on data from www.ksh.hu

Besides demographic data, labour market position of the region, its option for future development paths is also an interesting question. The unemployment rate can be a measure of regional performance. The trend of the rate is the same in the region as at national level, but it is always higher than the national average for Northern Hungary. It has been increasing since 2012 and for four years it has been over 16 percent, while the national average has been below max 12 percent.

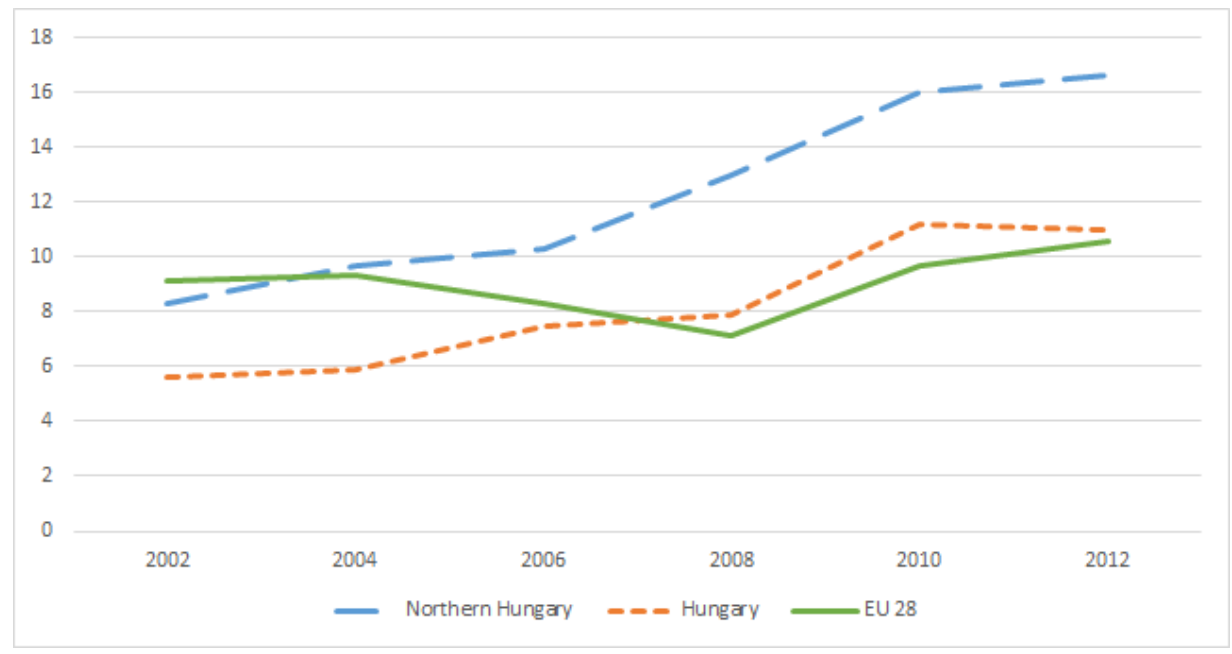

Figure 4. Unemployment rate (2002-2012)

Source: own compilation based on data from www.ksh.hu 


\section{A FEW EMERGING PRIMARY DATE FROM MY THE PASTS RESEARCHES}

In the region in 2011 year 514 secondary school students (17-19 year old) was surveyed. From them, 328 are girls and only a little more than a half, 184 were boys ( 2 pupils did not answered this question). The surplus of the girls in secondary schools (with no specification) is typical, but decreases from year to year. During the selection we tried to find a wide scope of trainings and locations. As we thought in the framework of the capital city-rural region opposites, we have chosen three county capitals (as peripheries in geographical and also in economical aspect) and a village next to one of the county capital to see, how great effect can be observed near a rural centre. The four towns where we selected the five schools are as follows: Miskolc, Eger, Salgótarján, Mezökövesd. On the whole, there was a positive attitude from the students' side regarding the answers. Analysing the way of life in the region, it was hopeful to see that one of the best average got the answer about family and the friends are more important for the students the than the career and the money 169 fully agreed from which 59 were boys. Pupils don not think that it would be very difficult to find a place of living elsewhere based on more than $65 \%$ of answers. The ration of the boys was lower, only $30 \%$ disagreed or fully disagreed, so it seems the home town stands closer for them. 480 pupils fully agreed (almost 95\%) that the protection and safe surrounding has very high importance.

\section{Intentions to migrate}

The results of the questionnaire study clearly show that that the biggest problem that are important causes of the further moving potential is the high unemployment rate that goes with poverty, the high ratio of roma minority, pollution and security of the places. 35 percent of the students also mentioned the inadequate mass transportation (that set back option for commuting) as push factor. Because of the adverse availability of the analysed areas (the county capitals are far from the centre of the country, so in geographical aspect - based on available population potential -)these are strongly peripheral or transitional areas that is less attractive because of the high availability times.Student think that there will be less and possibilities for them to find a workplace, and because of the chaotic situation in Hungary they can hardly trust also in the country. The following chart highlights also this situation: many students are planning to leave the region latest after graduation.

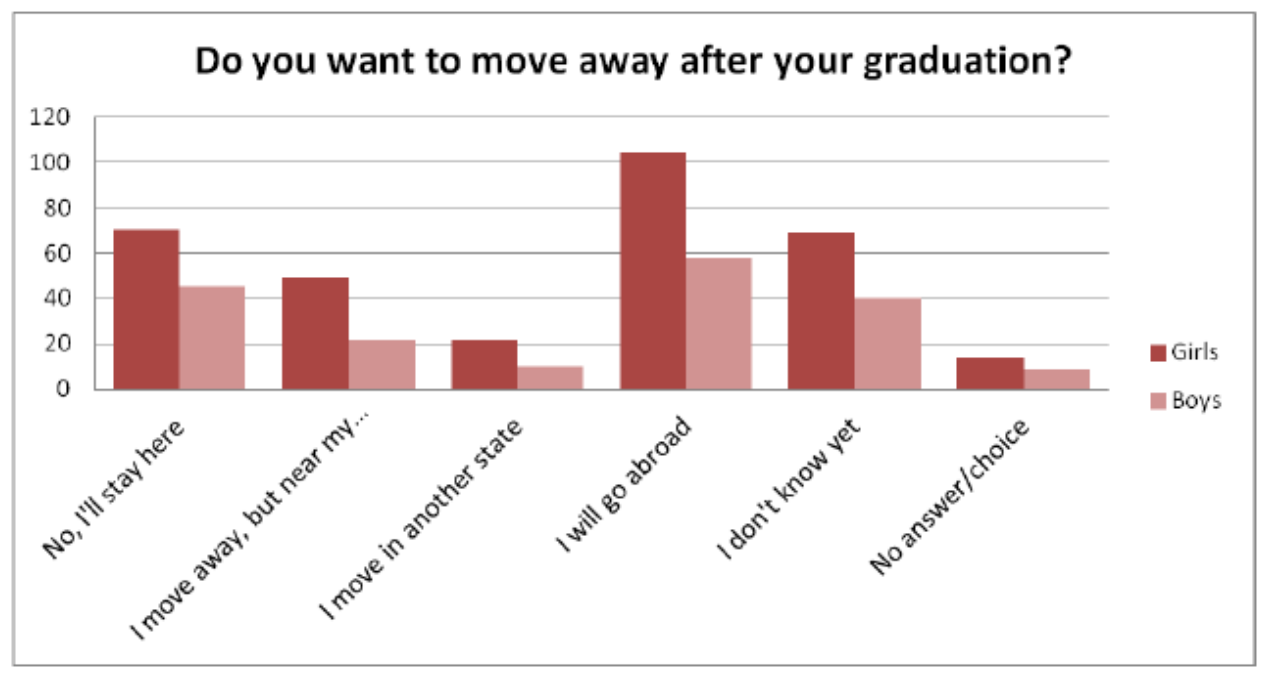

\section{Figure 5. Plans after graduation}

The family of the students also offers to leave the region, so the futureplan of these rural territories - outmigration, shrinking population, and growing share of elderly, low level safety - is distressing.Future plans/ExpectationsUnfortunately most of the students are planning to leave theregion before or latest after the higher education. Almost $80 \%$ of the students think that because of lack of jobs in the region, the liveable place in Hungary is proved to be only the capital city and its agglomeration. In 10 years time concerning the aims, the answers were unambiguous: in total, most of the students ( 246 girls and 113 boys) want to have a 
family firstly, than professional career (221 girls and 128 boys) - here the ranking was opposite in the case of boys. On the third place peaceful life comes, with 143 yes from the girls and 81 from the boys. Networking with interesting people and ensuring peaceful and quiet life, securing the environment are also among the most important goals of the pupi. $30 \%$ of the boys and $32 \%$ of the girls plans that they will work in abroad 10 years later. Unfortunately, only $24 \%$ of the boys and $21 \%$ of the girls are going to stay at their present location - mostly because of the family. 112 pupils (38 boys 73 girls) go abroad, while 109 students still do not know, if they want to move or not. For many students are sure that they will come back (54 girls, 53 boys), 198 answered with „maybe” (138 of them were girls).

During the research we have made interviews also experts who are affected by the problem of women outmigration and able to give some advices to the regional policies.

All of the experts agreed that it is a relevant problem that the number of children is decreasing in the region. Great number of the unemployed livein the territory, that fact strengths out-migration processes and decreases towards the population. Unemployed and employees with lower incomerepresent poor consumption demand that has a negative effect on the economy.Experts from the education sector mentioned as further problems that the supply and demand at the labour market does not meet. The labour force does not have proper qualification; therefore, their chances on the labour market continuously worsen. It also affects the tendency that the qualified work force and young people with higher education degrees migrate.This is a vicious circle: the unfavourable tendencies mentioned above discourage investors and prevent new businesses from moving to the region, so there is no chance to create workplaces that affects further the outmigration. For example, secondary school education is mostly concentrated to largecities, as we also saw this trend during the questionnaire. Secondary, with key roles played in this respect by county centres, which offer a wide range of schools that take more than half of secondary school pupils, while there are some micro regions that does not have secondary school these are early forces for children to leave their hometown at the very beginning.In the national and regional documents there is not so many concrete referring to the situation of the women, because this problem affects the whole young population. (Kocziszky et al. 2012 in project SEMIGRA)

\section{WILLINGNESS TO WORK ABROAD IN MEDICAL SOCIETY OF THE COUNTY IN 2004 AND EMIGRATION PROPENSITY OF SKILLED WORKERS IN HEALTHCAREIN IN 2006}

As I have already proved in the first two chapters, the emigration of the highly qualified workforce adversely affects the competitiveness of the region. Therefore I considered it important to carry out stratum surveys, especially in the endangered labour market segments. The Association of Hungarian Medical Society (MOTESZ), having reviewed the shortage of professionals in medical fields in 2003, claimed that there was a general shortage of professionals in healthcare. They warned that this would be even worse after the EU accession.I had a closer look at this problem in a questionnaire survey, done in 2004 under my supervision, about the emigration potential of the doctors in Borsod-Abaúj-Zemplén County. Later, in 2006, we carried out a survey relating to the willingness to work abroad of students of the Medical College of Miskolc.The findings of the primary survey suggest that the gross migration willingness of the medical society exceeded the results of total county sample. $80 \%$ of the respondents gave a "yes" answer to the question "Do you find working abroad attractive?". 60\% answered "yes" to the question "Would you work abroad if you had opportunity". $60 \%$ of those who would potentially like to work abroad would leave Hungary for a while, $34 \%$ of them would leave Hungary for any long period of time and $6 \%$ of them would permanently settle down abroad.The motivation factors could be ranked in order of importance as follows: higher earnings, expansion of professional experiences, greater professional appreciation, learning languages and seeking adventure. Those who did not hold working abroad attractive mostly were afraid of the unknown.

The objective of the primary survey carried out in 2006 was to get to know the proportion of emigration propensity and the in the Miskolc Faculty of Medicine. We were also interested in what motivates people to work abroad. 58\% of the respondents feel like working abroad after getting diploma. $49 \%$ of them would stay abroad for good.It is the greater earning which predominantly motivates respondents. Improving languages skills and gaining professional experiences proved to be the least attractive for the students. Better working conditions were more important for students than higher working standard. The medical society of Borsod- 
Abaúj-Zemplén County has some interest in migrating abroad: this is a conclusion that can be drawn from the survey. A further survey should be conducted in order to find out whether the wishes put forth by the respondents would be translated into actions, that is, whether they will take steps to find work abroad. Improving human potential is an essential condition of the economic development of North Eastern Hungary. It is inconceivable without healthcare professionals who take responsible for the region. Retaining them is of key importance, and requires a long-term development strategy.

Regional (economic) policy is more and more important in the $21^{\text {st }}$ century. Strategies relating to migration are essential part of economic policy.

A basic assumption of this chapter is that migration is primarily a question of national security and secondarily it is an economic issue. That is, its labour market aspect tends to be neglected, which I think is a wrong approach. Although I am aware that the international agreements determine the political, legal and economic life, I suggest that the national employment policy should place more emphasis on managing migration in order to decrease the negative effects of the emigration processes and make use of the positive effects.

Hungary is a sender, a transit and a host country at the same time. That is why we should draw conclusions from other countries' practices. It is important to notice that migration influences growth, redistribution and the sustainability of the pension system. This process needs to be managed. Immigration, especially in the case of qualified workforce, may strengthen the domestic economic growth.

Apart from the potential benefits of immigration, the country has to prepare for the emigration of its labour force. Since qualified workforce is a key factor of competitiveness, one objective of a nation's economic policy is to utilize the knowledge of its citizens, so make sure if they move abroad temporarily, then having returned, they can make use of their experiences at home.

A geographical inequality is characteristic of the labour market in Hungary: the level of employment, the rate of unemployment and the inactivity rate differ by regions. Its reason has been different in the various decades after 1989 (change of regime) (Tóthné Sikora 2007).

\section{RECOMMENDATIONS CONCERNING THE REGIONAL MIGRATION STRATEGY}

I formulated different scenarios at the end of my research using the GEO4 report as a basis:

Market solution: The achievement of human prosperity is facilitated through the support of the private sector. That is, the government strives to create favourable domestic conditions for the workforce; and to adopt market-compatible solutions to mitigate the adverse effects of migration.

Political solution: The government is able to stop emigration using political tools. It also attracts knowledge in order to help backward regions. It runs state-owned research institutes and supports educational institutions in the country; it concentrates the state investments in the lagging regions.

Safety: Here the government and the private sector compete for the control. It is important from the point of view of migration because in this case there are scenarios in which self-regulation and re-burdening have role.

Sustainability: It entails the cooperation of the private sector, the society and the government in order to ensure human welfare. (Labour) migration develops in a way that the labour markets of the less developed countries of Europe are able to reproduce themselves: in this way the systems of the welfare-state based on redistribution will not collapse; the classical social insurance system is able to work.

Strategies are based on interests: they are the interests that answer the question why a strategy is necessary and the environment determines where the strategy should be implemented.. In order to lay the groundwork for migration strategie, I designed the PAD model which is presented below: 


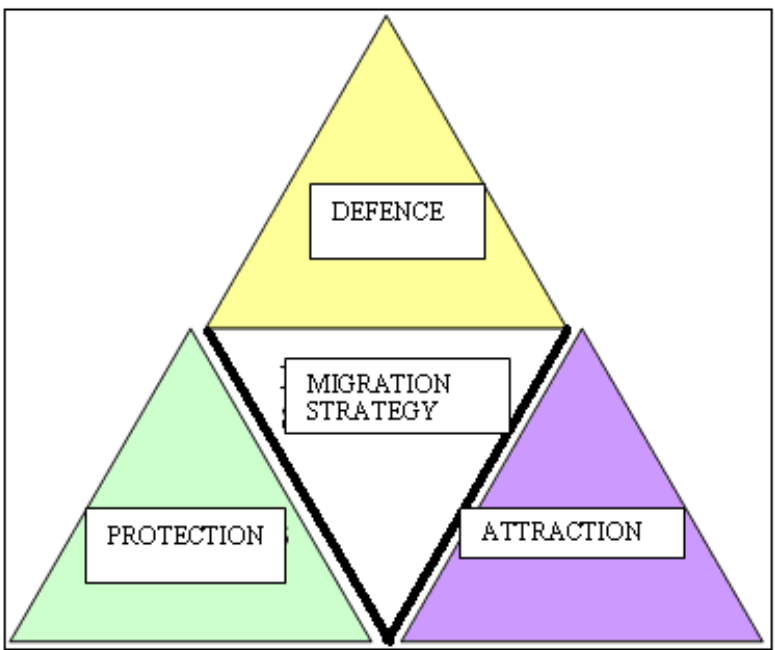

\section{Figure 6. PAD Concept of Migration}

Protection: means to curb the immigration jeopardizing the County, the objective of which is to maintain the fragile peace of the society. Although emphasis of my dissertation was to call attention to the losses caused by emigration, one has to pay attention to immigration as well. On the one hand, I assert that a strong and selective procedure of getting residence and work permit is necessary. However, EU citizens' migration should not be administratively hindered. One way of protection is strengthening the national self-awareness, interpreted in its correct meaning. This means, that Hungarian employees or employees from the County should enjoy preference. On the other hand, the society and the people employed in infrastructure facilities should be prepared for the rippling world-tendency that more and more foreigners will settle down.

Attraction: Due to-loss of population (natural loss and emigration), the demographical self-reliance of the County has become less and less. The labour market trends, as I have proven earlier, clearly necessitate supplementing the loss of the population from external sources. The demand is twofold: highly qualified workforce with innovative marketable knowledge and highly skilled workers are needed. Similarly to the theory of the American migration policy, the migration strategy has to support immigration of artists, doctors and people coming from afar because their presence may revitalize competition.

Defence: refers to retain the population born in the County to decrease the willingness to emigrate. It is essential that policy makers concentrate on people with outstandingly good skills (innate and gained competences). Two solutions are recommended at this point: on the one hand establishing local educational and research bases, financing and supporting public education. Areas of the County in bad social conditions also need special attention for economic reasons. (Dabasi 2009)

\section{CONCLUSION}

I carried out my primary and secondary surveys within the boundaries of economic paradigms. That is, the various economic theories cannot clearly define either the direction or the extent of the migration processes but they have an explanatory power that should be taken into consideration in surveys preceding policymaking. Afterwards I mapped up the immigration propensity of the County's population. I demonstrated their relation to working abroad in the light of the EU accession. I separately analyzed the migration potential of health-care employees who are especially subject to brain-drain.

The main conclusion of my article is that whereas the economic and sociological theories deal with the impacts of migration on the host countries, the negative impacts occurring in the sender countries will be important in the 21 st country. The competitiveness of a region is determined by the composition of the labour force both in terms of quality and quality and also its ability to retain its population. The task of a region's economic policy is to attract, retain, motivate and to efficiently manage its population which includes that migration strategy is art of its employment policy. Tools that would be able to treat the rapidly growing lack of balance are missing in the labour market. The competitiveness is jeopardized by the lack of coordinated 
migration strategy that would protect the labour market. It is a great loss for Hungary if its investment into the human capital is harvested by other countries. Retaining workforce should get a greater role in the employment strategy.

\section{FUTURE RESEARCH PROSPECTS}

How can the mobility of young people be 'good' both for socio-economic development and for individual development of young people, and what are the factors that foster/hinder such beneficial mobility?

The project will investigate different patterns and types of mobility of young people with quantitative and qualitative data collection and analyses in collaboration with institutions from six European countries: Luxemburg, Romania, Hungary, Germany, Norway and Spain. Research's project will take into consideration different aspects of social inequality such as migration background, gender, educational inequalities, impairments and disabilities. 


\section{REFERENCES}

Bauer T.-Zimmermann K. F.: (1999) Assessment of Possible Migration Pressure and its Labour Market Impact I ZA Research Report No. 3 Bonn July

Benton, M., and Petrovic, M. (2013), 'How Free Is Free Movement? Dynamics and Drivers of Mobility within the European Union' $<$ http://www.migrationpolicy.org/research/how-free-free-movement-dynamicsand-drivers-mobility-within-european-union>, accessed 10 Apr 2014.

Bourdieu, P. (1984), Die feinen Unterschiede. Kritik der gesellschaftlichen Urteilskraft (Frankfurt a. M.: Suhrkamp).

Bukodi, E., and Róbert, P. (2007), 'Occupational mobility in Europe' <http://www.eurofound.europa.eu/pubdocs/2007/11/en/1/ef0711en.pdf>, accessed 8 Apr 2014.

Bynner, J. (2005), 'Rethinking the Youth Phase of the Life-course: The Case for Emerging Adulthood?', 8: 367-384, Journal of Youth Studies.

Castles, S (1986.) The Guest Worker in Western Europe - an Obituary, In: International

Migration Review, 20. sz. pp. 761-779.

Dabasi Halász, Z. (2009), 'Winners and Loosers! Strategic factors and tendencies of international migration in Borsod-Abaúj-Zemplén County’ PHD Thesis Miskolc

Ecclestone, K., Biesta, G., and Hughes, M. (2010), Change and becoming through the lifecourse: Transitions and learning in education and life (London: Routledge).

Elder, G. H. (1995), 'Life Trajectories in Changing Societies', in A. Bandura (ed.), Self-Efficacy in Changing Societies (Cambridge: Cambridge University Press), 46-68.

Frändberg, L. (2014), 'Temporary Transnational Youth Migration and its Mobility Links', Mobilities, 9/1: $146-164$.

Glick Schiller, N., and Levitt, P. (2008), 'Conceptualizing Simultaneity: A Transnational Social Field Perspective on Society', in S. Khagram (ed.), The transnational studies reader. intersections and innovations (New York, NY [u.a.]: Routledge), 284-94.

Growiec, K. (2010), 'Social Capital and Migration: The Case of Polish Youth', in D. Cairns (ed.), Youth on the Move. European Youth and Geographical Mobility (Wiesbaden: VS Verlag für Sozialwissenschaften / GWV Fachverlage GmbH, Wiesbaden), 35-47.

Harris J. - Todaro M1970: Migration, Unemployment \& Development: A Two-Sector Analysis. American Economic Review, March

Kuhlenkasper, T. (2012), 'Who leaves and when? Selective outmigration of immigrants from Germany' <http://www.hwwi.org/uploads/tx_wilpubdb/HWWI-Research-Paper-128.pdf>, accessed 22 Apr 2014.

Kocziszky Gy 2012 SENIGRA project This paper is the ESPON targeted research project Selective Migration and Unbalanced Sex Ratio in Rural Regions (SEMIGRA).

Mills, M., and Blossfeld, H.-P. (2005), 'Globalization, uncertainty and the early life course', in H.-P. Blossfeld, E. Klijzing, M. Mills et al. (eds.), Globalization, uncertainty and youth in society (London, New York: Routledge), 1-24.

Malthus, T. R.: (1798) :In:1982: Tanulmány a népesedés törvényéröl. In: Népességrobbanás - egyke., Bukarest, pp. 61-21 (An Essay on the Principle of Populatio)

Piore, M. J. (1970): Manpower Policy. In: Samuel Beer et al. (eds.) The State and the Poor. Boston: Winthrop Publishing Co.

Portes, A. (1981): Modes of structural incorporation and present theories of immigration. In: M. M. Kritz et al (eds): Global Trends in Migration. New York: Center for Migration Studies 
Priestley, M., and Biesta, G. (in press/2014), Teacher agency: An ecological approach (London: Bloomsbury).

Queirós, J. (2010), 'Recent Economic Performance and Changing Configurations of Workforce Mobility in Northwest Portugal: Social Consequences of Unemployment and the Rise of Youth Emigration', in D. Cairns (ed.), Youth on the Move. European Youth and Geographical Mobility (Wiesbaden: VS Verlag für Sozialwissenschaften / GWV Fachverlage GmbH, Wiesbaden), 95-106.

Raghuram, P. (2009), 'Situating Women in the Brain Drain Discourse: Discursive Challenges and Opportunities', in H. Stalford, S. Currie, and S. Velluti (eds.), Gender and migration in 21st century Europe (Law and migration, Farnham, England, Burlington, VT: Ashgate Pub.), 85-106.

Raithelhuber, E. (2011), Übergänge und Agency: Eine sozialtheoretische Reflexion des Lebenslaufkonzepts (Leverkusen [u.a.]: Budrich UniPress Ltd.).

Ravenstein, E. G (1889) The Laws of Migration, Journal of the Royal Statistical Society, London, June, pp. 241-301.

Sassen, S. (1988): The mobility of labor and capital: a study in international investment and labor flow. Cambridge: Cambridge Univ. Press.

Swaan W. (1994): Tudás, tranzakciós költségek és a transzformációs válság. Közgazdasági szemle, 41.(10), 845-858. p., (ISSN 0023-4346)

Schumpeter J.(1980): Methodological Individualism Brussels: Institutum Europæum. English translation by Michiel van Notten of the corresponding chapter of Joseph Schumpeter(1908) URL:

http://mises.org/books/schumpeter_individualism.pdf (Accessed 26 June 2009). at http://www.archive.org/details/daswesenundderh00schugoog[unfortunately pp 98-99 are missing, however] (Accessed 26 June 2009).

Skrobanek, J., Reissig, B., and Müller, M. (2011), 'Successful placement or displacement in the transition from school to vocational training: the case of lower secondary school pupils', Journal of Youth Studies, 14/7: 811-837.

Snel, E., and Engbersen, G. (2006), 'Transnational involvement and social integration', Global networks : a journal of transnational affairs, 6/3: 285-308.

Stalford, H., Currie, S., and Velluti, S. (2009a), 'Conclusions', in H. Stalford, S. Currie, and S. Velluti (eds.), Gender and migration in 21 st century Europe (Law and migration, Farnham, England, Burlington, VT:

Ashgate Pub.), 241-5.

Tobler, W (1995) Migration: Ravenstein, Thorntwaite, and Beyond. Urban Geography, Vol. 16, No. 4, pp. 327-343.

www.geog.ucsb.edu/ tobler/publications/pdf_docs/movement/migration/Ravenstein.pdf.

Wallerstein, I. (1983) Historical capitalism Verso, ISBN0860917614, 9780860917618 pp.100 